Síntese: Revista de Filosofia adere a uma Licença

\title{
CRISTIANISMO E HISTÓRIA: O APELO QUENÓTICO DE ENFRAQUECIMENTO AO CRISTIANISMO EM GIANNI VATTIMO
}

Christianity and history: The kenotic call for the weakening of Christianity in Gianni Vattimo

Marcelo Martins Barreira*

Resumo: $\mathrm{O}$ enfraquecimento da metafísica é um apelo da Kénosis divina ao atuar historicamente secularizando hierofanias violentas a favor de uma intensificação do projeto ético-político democrático. Por isso, o esvaziamento do "sagrado natural" presente no "cristianismo trágico" em sua fundamentação metafísica no Totalmente Outro faculta novamente a que nossos contemporâneos escutem o apelo da fé. Em sua hermenêutica do religioso, Gianni Vattimo articula o pensamento de Nietzsche e Heidegger com a ação quenótica de superação da metafísica como historicização do cristianismo. $O$ anúncio da morte do Deus-moral e a dissolução do sagrado-violento enfraquecem quenoticamente as estruturas do pensamento objetivante do ser, facultando a pluralidade de pontos de vista sobre o mundo e sobre o cristianismo.

Palavras-chave: Kénosis. Tradição. Enfraquecimento. Cristianismo. Vattimo.

Abstract: This article approaches Christianity and its history from the hermeneutic perspective of Vattimo. The first part analyzes the relationship between Nietzsche's and Heidegger's thought and the kenotic action of overcoming metaphysics as historicization of Christianity. The second part deals with the weakening of

* Doutor em Filosofia pela Unicamp. Professor do Departamento de Filosofia da Universidade Federal do Espírito Santo (Unifes). Artigo recebido em 30/06/2020 e aprovado para publicação em 20/10/2020. 
metaphysics as response to an appeal for the divine Kenosis to secularize violent hierophanies, in order to further the democratic and ethical-political project. Consequently, the "natural sacred" is removed from "tragic Christianity" in its metaphysical foundation in the Totally Other. The announcement of the death of the moral God and the dismantling of the sacred-violent therefore weaken the structures of the objectifying thought of being and provide a plurality of perspectives on the world as well as on Christianity, opening the latter to an effective historicity of its tradition.

Keywords: Kenosis. Tradition. Christianity. Weakening. Vattimo

\section{Introdução}

A produção de Gianni Vattimo quanto ao cristianismo e história se assenta numa tripla articulação entre cristianismo, hermenêutica e democracia. Essas características norteiam sua análise hermenêutica sobre os fenômenos culturais e religiosos e, paradoxalmente, coloca-se sob o influxo da ação quenótica como sinal de nossa ambiência ética, política e cultural.

De início, sublinhemos um contraponto da hermenêutica vattimiana com a fenomenologia como leitura filosófica do religioso. A hermenêutica filosófica - em estreita relação com a tradição quenótica - adquire contornos de divergência com o enfoque fenomenológico do religioso por conta da tarefa hermenêutica de esvaziar a objetivação do real. Objetivação expressa fenomenologicamente na busca do sagrado-em-si como a "essência das

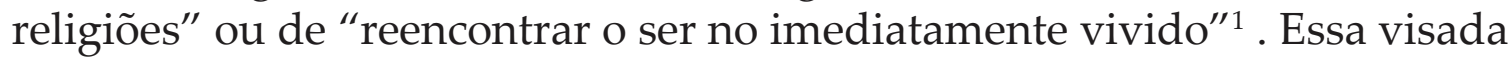
se traduz na absoluta verticalidade de Deus como o "Totalmente Outro" (ganz andere), de Rudolf Otto, e assumido na fenomenologia da religião por Mircea Eliade ${ }^{2}$ que desconsidera a incomparável distinção de visões do sagrado para reduzi-las a uma única definição essencial.

Do ponto de vista hermenêutico, não é possível uma abordagem ahistórica do religioso como fez Eliade ao preconizar uma essência sagrada do religioso. O religioso carrega um sagrado que acontece cultural e historicamente e não enquanto essência universal. O religioso é histórico e a historicidade do cristianismo demanda um caminho de aproximação, o mais próximo possível, do fenômeno em acontecimento. Nesses sagrados fenomênicos, a hermenêutica tem em vista a ineficácia de se conceitualizar o sagrado-em-si e não priorizar a diversidade de sagrados nas várias expressões culturais dos fenômenos religiosos; por isso, no caso do Ocidente, partiremos do

\footnotetext{
${ }^{1}$ VATTIMO, G. Acreditar em acreditar, 1998, p. 22.

${ }^{2}$ ELIADE, M. O sagrado e o profano, 2001, p. 16.
} 
cristianismo em geral, em que pese a variedade de suas formas. Seja como for, a hermenêutica visa encontrar o sentido do religioso não pela ênfase na transcendência, própria ao horizonte da fenomenologia, mas na imersão histórica que enfatiza a sua plural manifestação cultural.

As contribuições de Vattimo enfocam a tradição religiosa, notadamente a cristã, como oportunidade alvissareira diante de um futuro incerto. Sua inovadora hermenêutica do cristianismo faz dele referência para uma ampla revisão no modo de compreensão da esfera religiosa; revisão em vista de sua atualização significativa na sociedade contemporânea enquanto época do fim da metafísica. Esse horizonte não visa, contudo, uma epistemologia de acesso à verdade revelada e sim uma retomada inclusiva e histórica do núcleo quenótico operante no empreendimento hermenêutico a partir de um reencontro plural do religioso em contexto democrático, em sua acepção ampla, seja como forma de vida e seja como regime político.

\section{I - A historicização da herança cristã}

A abordagem da herança cristã é fruto da ação quenótico-emancipatória que opera hermeneuticamente nessa mesma herança. Esse duplo processo é, portanto, de fundo cristão e "ocidental", posto que foi nessa específica cultura religiosa e nessa sociedade que a democracia floresceu. No tocante à interface político-cultural entre cristianismo - numa visão ampla e sem entrar nos pormenores denominacionais - e hermenêutica, ressalte-se como âmbitos culturais da tradição ocidental foram plasmados pelo cristianismo e, na esfera filosófica, a hermenêutica filosófica participa da circularidade entre filosofia e religião cristã em sua modernidade tardia - após a sufocante racionalidade instrumental e técnica de apropriação do real, cuja pretensa neutralidade axiológica seria como "arrancar os olhos para ver objetivamente as coisas" ${ }^{\prime 3}$.

Para romper com tal objetivismo e compreender o real como acontecimento e liberdade, nosso autor partiu da fonte cristã como base paradoxal da secularização europeia e das propostas pós-metafísicas de Nietzsche e Heidegger. ${ }^{4}$ Dessa maneira, uma das centralidades do empreendimento hermenêutico é o esvaziamento do ênfase causal da técnica, de acordo com a análise heideggeriana, diferenciando-se do aspecto apenas mental da metafísica aristotélica; contudo, ambas estabelecem relações entre objetos pelo princípio de causalidade. ${ }^{5}$ No bojo dessa apropriação heideggeriana

${ }^{3}$ VATTIMO, G. Acreditar em acreditar, 1998, p. 38.

${ }^{4}$ VATTIMO, G. Acreditar em acreditar, 1998, p. 23.

${ }^{5}$ VATTIMO, G. Etica dell'Interpretazione, 1989, p. 66. 
da metafísica, Vattimo concebe uma ontologia "enfraquecida". O enfraquecimento das estruturas fortes da metafísica não é a negação da metafísica, pois sua negação teria a mesma impostação da verdade metafísica sobre o real, que "identifica o ser com a objetividade e o fundamento" 6 - identificação que se percebe na pretensão socrático-platônica de aceder a um óntos ón ${ }^{7}$.

Do enfraquecimento (indebolimento) da metafísica vem a expressão pensiero debole como "teoria do debilitamento como traço constitutivo do ser na época do fim da metafísica" 8 - note-se que, portanto, embora associável a algo quebrável (fragile), a acepção do termo debole vai ao encontro da palavra "fraco", incidindo no ato democrático de identificação com os mais fracos:

O pensamento fraco é também, um pensamento que respeita a esperança da maioria, no fundo, um pensamento autenticamente democrático. Eu estou com os fracos porque, em muitos sentidos, sou um deles, e não porque haja para mim uma razão metafísica para preferi-los. ${ }^{9}$

A situação política e cultural se enreda num mecanismo de objetivação do ser, e do humano, plasmado pela racionalização instrumental que associa o real com o cálculo, a mensurabilidade e a manipulabilidade técnico-cientifica ${ }^{10}$. Desse modo, a objetivação industrial se escora na força de trabalho dos fracos ao alheá-los aliená-los de sua experiência cotidiana. Por isso, tal objetivação sintetiza o maior obstáculo para entender o humano na modernidade tardia. A diluição dessa objetivação metafísica do ser implica em relações éticas favoráveis ao outro.

O autor italiano ilustra a sua abordagem pós-metafísica da ética pela figura de um pai dirigindo um automóvel com sua família. Para que dirija com prudência, funciona mais a persuasão valorativa como a recordação afetiva de seus filhos do que a abstração de uma norma calcada num princípio objetivo de fundamentação metafísica. Esse exemplo mostra que a hermenêutica filosófica não é tanto uma teoria ou um método e sim uma filosofia prática:

A compreensão é algo mais que a aplicação artificial de uma capacidade.

É sempre também o atingimento de uma autocompreensão mais ampla e profunda. Mas isto significa que a hermenêutica é filosofia e, enquanto filosofia, filosofia prática. A grande tradição da filosofia prática sobrevive em uma hermenêutica que tem consciência de suas implicações filosóficas. ${ }^{11}$

\footnotetext{
${ }_{6}^{6}$ VATTIMO, G. Depois da cristandade, 2004, p. 113.

7 VATTIMO, G. Depois da cristandade, 2004, p. 53.

${ }^{8}$ VATTIMO, G. Acreditar em acreditar, 1998, p. 25.

9 VATTIMO, G. Entrevista: O capitalismo..., 2008b, p. 15.

${ }^{10}$ VATTIMO, G. Acreditar em acreditar, 1998, p. 20.

${ }^{11}$ GADAMER, H-G. A Razão na época da ciência, 1983a, p. 76.
} 
Temos, então, na citação acima de Gadamer uma hermenêutica como filosofia prática e que transforma a ética em hermenêutica ${ }^{12}$. Dessa amplitude gadameriana, Vattimo tece originais desdobramentos políticos. Retomando a Tese sobre Feuerbach, de Marx, Vattimo afirma: "Interpretar o mundo é transformar o mundo"13. Essa extensão ético-política exprime que a hermenêutica "não é apenas o cerne da cultura humanista e das ciências espirituais de fim de século; é também, acho que podemos dizer, uma ontologia real de assuntos atuais." ${ }^{14}$ Cuja atualidade adquire uma perspectiva global e uma vocação comunista num sentido lato, ${ }^{15}$ contendo o risco de uma tendência nazista e sem a necessidade lógica de "superação dialética da realidade, na linha hegeliano-marxista, que se dá ao modo metafísico tradicional por conta de sua pretensão fundamente do real." Daí que, ante o imenso bazar de visões de mundo - "onde se cruzam e convivem diversos sistemas de valores"16 - torna-se central o jogo democrático de pontos de vista, mesmo quanto ao religioso.

O mergulho contingente em nossa ambiência cultural e política corrobora a hermenêutica filosófica - em face de um democrático bazar de interpretações -; rejeitando a crença exclusiva nos experimentos das ciências da natureza, em oposição ao saber mítico - com o agravante de que uma justaposição do cientificismo com o iluminismo produziu uma narração evolucionista e eurocêntrica promovida pelo "desencantamento", conforme a célebre expressão de Weber ${ }^{17}$.

Contra uma restritiva definição de "desencantamento", Vattimo aponta a contraditória feição epocal do "desencantamento" moderno, pois "o desencanto do mundo produziu também um radical desencanto da própria ideia de desencanto". ${ }^{18}$ Essa contradição do desencantamento ou da liquidação cientificista de mitos, acabou sendo uma idealização "mítica" numa dupla acepção: 1) alegação de falsidade, em conformidade com o senso comum; 2) narração "sagrada" porque inquestionável. ${ }^{19}$ No entanto, para a tese weberiana não cair numa fixidez temporal das raízes cristãs da secularização ocidental, Vattimo retoma a denúncia nietzschiana do "excesso de consciência historiográfica" ${ }^{20}$, já no século XIX.

O excesso de erudição a respeito da "história" impede o reconhecimento do novo da história, que surge enquanto acontecimento e liberdade. Uma condição "necessária" não configura um "acontecimento" que, por defini-

${ }^{12}$ VATTIMO, G. Etica dell'Interpretazione, 1989, p.1 35.

${ }^{13}$ VATTIMO, G. Essere e dintorni, 2018, p. 325.

${ }^{14}$ VATTIMO, G. Essere e dintorni, 2018, p. 335.

${ }^{15}$ VATTIMO, G. Essere e dintorni, 2018, p. 129.

${ }^{16}$ VATTIMO, G. Acreditar em acreditar, 1998, p. 45.

17 WEBER, M. A ética protestante ..., 2004.

${ }^{18}$ VATTIMO, G. Acreditar em acreditar, 1998, p. 18.

${ }^{19}$ VATTIMO, G. Acreditar em acreditar, 1998, p. 18.

${ }^{20}$ VATTIMO, G. Acreditar em acreditar, 1988, p. 21. 
ção, irrompe enquanto novidade. O que acontece a modo de liberdade não possui uma teleologia ou necessidade histórica intrínseca. Apenas como acontecimento e liberdade há história e se pensa o ser como evento. A visão pós-metafísica é a do ser como evento e evento que vem a mim a modo de quando se reza, ou seja, um evento que nos acontece por uma iniciativa que não é minha, ${ }^{21}$ sobrepassando-nos.

Por isso, a secularização favorece o reencontro discreto e enfraquecido do religioso, muito diferente do fundamentalismo. Vattimo defende uma forma de se retomar a autêntica herança religiosa ocidental como uma enfraquecida proveniência e como fonte da secularização da violência de certas concepções do sagrado. A questão central, então, é o legado do cristianismo não se orientar historicamente por seu passado muscular e sim pelo esvaziamento divino Kénosis proclamado na Carta aos Filipenses. ${ }^{22}$ Para tanto, o reencontro com o religioso exige duas operações hermenêuticas marcadas pela tensa relação entre ação quenótica-secularizante e tradição cristã: o cristianismo transmite (Ueberlieferung) a Kénosis de Deus e a democratização no campo religioso aciona a Kénosis no cristianismo. ${ }^{23}$

A ação quenótica desmistifica o cristianismo e nos traz o que dele nos resta: a vitalidade de sua mensagem histórica da salvação, que está na origem de muitas conquistas civilizatórias como os Direitos Humanos; por isso, a matriz quenótica - que vem a nós de modo não-necessário - não interdita a pujança da proposta pós-metafísica vattimiana, sem causalidade necessária, do acontecimento do ser no campo religioso ocidental. Nessa linha de pensamento, Vattimo indica um influxo quenótico nos empreendimentos hermenêuticos de Nietzsche e Heidegger em prol da dissolução da visão unilinear e etnocêntrica de uma metafísica da história. Dissolução essa que foi uma paradoxal conquista do Ocidente, provavelmente por conta da incrementação cristã da alteridade nessa herança cultural. Assim, a Kénosis rompe com o etnocentrismo para favorecer uma filosofia da pluralidade de visões sobre o religioso em geral e o cristianismo em particular:

A secularização desmistificadora que a fé nos convida a realizar em relação à "história" é sempre qualificada e historicamente comprometida e, portanto, tributária de outras mitologias e de outras histórias das quais não prescinde, tal como não pode por de parte a sua própria individualidade ${ }^{24}$.

O mito de um Deus-humanizado numa específica etnia, a hebraica, não preconiza uma necessidade étnico-cultural do cristianismo como se fosse uma "religião atávica 'natural"', 25 pois um Deus que sai de si coopera

\footnotetext{
${ }^{21}$ VATTIMO, G. Acreditar em acreditar, 1998, p.9 2.

${ }^{22}$ Fil 2,7.

${ }^{23}$ GIORGIO, G. Il pensiero di Gianni VATTIMO, G. 2006, p. 264.

${ }^{24}$ VATTIMO, G. Acreditar em acreditar, 1998, p. 78.

${ }^{25}$ VATTIMO, G. Acreditar em acreditar, 1998, p. 14.
} 
consideravelmente para que qualquer etnia não se feche em si mesma e em seu sagrado natural, abrindo-se universalmente para além das rígidas fronteiras culturais.

Para sustentar sua hipótese interpretativa, Vattimo retoma as grandes linhas do pensamento de René Girard. Embora de formação antropológica, Girard elabora uma teoria da origem da coletividade social a partir da relação entre o sagrado e a violência. Na obra A Violência e o Sagrado ${ }^{26}$, René Girard lança uma hipótese sobre a origem da sociedade pela associação das hierofanias "primitivas" com a violência. ${ }^{27}$ Segundo ele, haveria um impulso de imitação que operaria pelo desejo do desejo do outro, concretizando-se na apropriação de suas coisas e gerando uma originária conflitividade. Conflito esse só "solucionável" pela eleição de uma vítima a ser sacrificada como fator de aglutinação coletiva. Dessa maneira, a constituição comunitária e a extinção da violência generalizada passa por uma lógica de expiação e pelo posterior culto dessa vítima "sagrada" e "sacrificada" - quase a totalidade dos povos se constituíram por essa lógica mimética que culmina num ritual de culto a essa vítima.

A Bíblia, contudo, apresenta uma ambiguidade. Esses traços do sagrado "natural" se fazem presentes nela ao se conceber Jesus Cristo como a "vítima perfeita"; com sua execução, aplacando o sadismo da justiça divina perante a ofensa da queda original. Alternativamente, há o vínculo da justiça divina com a infinita misericórdia, frustrando a violência do sagrado natural. Apesar dessa vertente não-expiatória, foi a presença de elementos comuns às religiões sacrificais no judaísmo de então que condenou Jesus Cristo ao sacrifício na cruz, graças à não tolerância desses grupos religiosos ao anúncio de uma revelação amorosa e em franca ruptura com a lógica vitimaria da restritiva concepção do "sagrado natural" e os traços fortes e violentos de suas hierofanias.

Ainda hoje, mesmo em meios cristãos, a lógica expiatória da concepção violenta de sagrado natural e sua justiça divina continua presente em teologias naturais de cunho metafísico e ahistórico. A ênfase na dureza, na severidade e na "pureza" como rigor da justiça divina, deixa de lado a redenção amorosa. Um exemplo politicamente relevante para Vattimo seria não relativizar a afirmação da "moral 'natural"', ${ }^{28}$ de matriz escolástica, de que a prática homossexual seria um vício contranatura. ${ }^{29}$ Embora se deva estar atento ao risco de menosprezo e até de violência dessa afirmação, não é esse o aspecto da violência reforçado por nosso autor. A pior violência não seria uma alteração da ordem natural do mundo de tradição

${ }^{26}$ GIRARD, R. A Violência e o Sagrado, 1990.

${ }^{27}$ VATTIMO, G. Acreditar em acreditar, 1998, p. 27.

${ }^{28}$ VATTIMO, G. Acreditar em acreditar, 1998, p. 67.

${ }^{29}$ VATTIMO, G. Entrevista: O meu problema de cristão... 2008a. 
aristotélica - "aquilo que impede a realização da vocação essencial da coisa" 30 -, mas o silenciamento do "outro", sobretudo por incompetência epistemológica. ${ }^{31}$ Eis a maior violência: a ultimidade quanto à verdade do discurso metafísico que alcança o óntos ón como ponto de chegada ${ }^{32}$, tolhendo ulteriores questionamentos e inviabilizando o diálogo ${ }^{33}$.

Concepções atemporais de "pureza" na moral sexual trairiam, de acordo com Vattimo, a revelação cristã que acontece historicamente. De um ponto de vista ético-político, o cristão deveria questionar justificativas de status quo a partir de valores atemporais por conta da ação quenótica que vincula encarnação e dissolução do sagrado-violento. A revelação, pela historicização quenótica-secularizante, liberta a sociedade ocidental moderna do sagrado natural da metafísica.

Tal ênfase na "secularização" - em que pese uma concepção complexa do termo, que não se encaixa na visão linear comum - tem em vista a especial contestação da metafísica religiosa, notadamente no cristianismo muscular da Cristandade. A Cristandade supriu o vácuo político-institucional da decadência do Império Romano, ${ }^{34}$ quando imperadores convertidos ao cristianismo convocaram concílios ecumênicos com o fito de estabelecerem uma unidade político-cultural em todo o Império - pretensão que, além de fomentar dissensões internas, normatizou demasiadamente seu aspecto doutrinal. ${ }^{35}$

\section{II - O enfraquecimento não-violento da herança cristã}

A ação quenótica como hermenêutica do cristianismo não reforça uma compreensão do "Deus do livro" como um autor soberano da Sagrada Escritura, que detenha sua verdade. A Kénosis sublinha, isto sim, o lançamento da nomeação do divino ao jogo da pluralidade interpretativa na comunidade dos crentes como condição para a sua revelação:

o Deus que se dá a nós só no livro, que não existe como uma realidade objetiva fora do anúncio da salvação que, de formas historicamente mutáveis e predispostas a uma contínua reinterpretação por parte da comunidade dos crentes, nos foi feito pela Sagrada Escritura e pela tradição viva da Igreja. ${ }^{36}$

\footnotetext{
${ }^{30}$ VATTIMO, G. apud PECORARO, Niilismo e (pós)modernidade, 2005, p. 23.

${ }^{31}$ VATTIMO, G. Acreditar em acreditar, 1998, p. 36.

32 VATTIMO, G. Nichilismo ed emancipazione, 2003, p. 148.

${ }^{33}$ VATTIMO, G. Nichilismo ed emancipazione, 2003, p. 57.

${ }^{34}$ VATTIMO, G. Acreditar em acreditar, 1998, p. 47.

${ }^{35}$ VATTIMO, G. Acreditar em acreditar, 1998, p. 50.

${ }^{36}$ VATTIMO, G. Depois da cristandade, 2004, p. 14-15.
} 
A revelação judaico-cristã expressa seus mitos fundantes sob a forma de livro. Assim, a "Palavra de Deus" vem associada às palavras humanas e se transfigurou numa ética de razoabilidade e numa política democrática aberta à pluralidade de visões de mundo. Cada comunidade de crentes se reencontra com o cristianismo quando sua mensagem de salvação adquire um contorno ético-político, associando-a aos sinais dos tempos. Sem preconizar uma horizontalização absoluta na esfera do humano, a tradição religiosa não prescinde de uma atmosfera política e cultural em que comunidades contextualizem a semântica religiosa com fidelidade e criatividade. ${ }^{37}$

$\mathrm{Na}$ tensão entre fidelidade e criatividade se tece comunitariamente uma interpretação da Escritura Sagrada diante do acontecimento do ser na história. No entanto, o sentido dessa narrativa se faz por sua capacidade de transformação do contexto de vida de cada crente em sua comunidade. Há, então, uma salutar experiência de culturalização do religioso por uma herança viva - vemos isso na ressignificação histórica e existencial da defesa luterana do "livre exame" da Sagrada Escritura ${ }^{38}$.

Uma ressignificação culturalizante do divino permite melhor "ouvir a palavra evangélica", ${ }^{39}$ pois a fé entra pelo ouvido, como consta na Carta aos Romanos, ${ }^{40}$ quando ela não é apenas ouvida, mas entendida e aplicada à vida. Desse modo, sua escuta se traduz numa resposta ética e política à revelação do esvaziamento de Deus por amor. Essa reinterpretação, atenta e amorosa da tradição, acontece na comunidade viva "daqueles que acreditam em Jesus Cristo".$^{41}$ Nessa relação amorosa, a encarnação se converte no núcleo da história da salvação por revelar uma visão "amigável" do divino com o humano, segundo o Evangelho de João. ${ }^{42}$ Um importante detalhe: a visão amigável do divino não torna fácil, leve e palatável a vida moral cristã; pois, ao se conceber Deus como amigo, aceita-se a revelação feita especialmente aos pequenos e enfraquecidos ${ }^{43}$; num engajamento com eles que universaliza a revelação para diversas situações de solidariedade.

A relação entre Deus e os humanos carrega leituras violentas e não violentas, não se trata aqui propriamente de conteúdo do texto, mas da atitude do leitor do texto bíblico. Correlato à Bíblia, há leituras violentas e não violentas também do "cristianismo". Como consequência, Vattimo analisa as duas versões do cristianismo, a violenta e a não violenta. Essas duas histórias se resumem em dois modelos gerais ou paradigmas hermenêuticos

\footnotetext{
${ }^{37}$ VATTIMO, G. Acreditar em acreditar, 1998, p. 85.

${ }^{38}$ VATTIMO, G. Acreditar em acreditar, 1998, p. 54.

${ }^{39}$ VATTIMO, G. Acreditar em acreditar, 1998, p. 73.

${ }^{40} \mathrm{Rm} \mathrm{10,} 17$.

${ }^{41}$ VATTIMO, G. Acreditar em acreditar, 1998, p. 93.

${ }^{42}$ Jo 15,15 .

${ }^{43}$ VATTIMO, G. Acreditar em acreditar, 1998, p. 25.
} 
do cristianismo de nossos dias: a tragicidade e a secularização quenótica pela caritas/pietas. Tais histórias do cristianismo, ainda que matizáveis e com possíveis interfaces, fornecem-nos diretrizes para uma renovação do próprio cristianismo.

O primeiro modelo é o do cristianismo trágico. A tradição trágica desincumbe o crente de uma ação política emancipatória, buscando num outro mundo o significado deste. A narrativa vattimiana aproxima a visão veterotestamentária ao jansenismo de Pascal e ao puritanismo de Kierkegaard, cuja impostação continuaria após Auschwitz, em autores como Emmanuel Lévinas e Jacques Derrida. ${ }^{44}$ Diversos acontecimentos catastróficos, em particular os campos de concentração nazistas, geraram desilusão quanto ao valor da razão moderna, contribuindo com a leitura de um destino trágico da revelação. As certezas iluministas ensejaram, como reação, uma antropologia calcada na culpabilidade e pecaminosidade. Junto a essa antropologia, adveio a busca por um sentido infinito e acima da trivialidade histórica, o que estabelece um hiato intransponível entre história da salvação e história secular.

Negando-se o empenho político transformador das estruturas injustas de poder, resta-nos um tempo de prova/purgação e o "salto na fé", consoante o relato do sacrifício de Isaac por seu pai, Abraão, ${ }^{45}$ conforme a interpretação feita desse relato por Kierkegaard na obra Temor e tremor ${ }^{46}$. Com a expressão "salto da fé", Kierkegaard indica a suplantação do ético pelo estado religioso. $\mathrm{O}$ "salto na fé" apela à infinita alteridade divina sem se comprometer com a tarefa emancipatória. Essa hermenêutica "trágica", na terminologia do autor turinense, evoca, de tal modo, a transcendência e alteridade absoluta de Deus que ele se transfigura no Totalmente Outro. Deus é o Totalmente Outro pela ênfase na descontinuidade entre os atributos divinos e as dilacerantes condições histórico-existenciais do humano. Há, então, um ocultamento da divindade (Deus absconditus), distinguindo-se da "teologia positiva".

No tocante à teologia positiva ou atributiva, a filosofia dos preambula fidei, de tradição tomista, prepara conceitualmente a ela, como o nome diz. ${ }^{47}$ Assim, a Teologia relacionada à Filosofia Natural atribui à divindade todos os atributos da transcendência como fundamento último do real, quais sejam: onipotência, absolutidade e eternidade, retomando os "traços de autoridade pessoal, próprios do Deus pré-metafisico da religião natural" ${ }^{48}$ A ideia abstrata e metafísica de Deus como Ipsum Esse Subsistens ${ }^{49}$ coloca

\footnotetext{
${ }^{44}$ VATTIMO, G. Acreditar em acreditar, 1998, p. 83.

${ }^{45}$ Gn 22, 1-18.

${ }^{46}$ KIERKEGAARD, S.A. Temor e tremor, 1979.

${ }^{47}$ VATTIMO, G. Acreditar em acreditar, 1998, p. 29.

${ }^{48}$ VATTIMO, G. Acreditar em acreditar, 1998, p. 83.

${ }^{49}$ VATTIMO, G. Acreditar em acreditar, 1998, p. 29.
} 
Deus como o ápice transcendente da cadeia hierárquica de analogia entre os entes (analogia entis); assim, o ser-em-si, Deus, referencia-se à estabilidade do ente, que, por definição, não se contaminaria pelo devir histórico.

Retomando o Deus absconditus da teologia negativa, Vattimo reporta esse modo de se fazer teologia ao kierkegaardiano "salto na fé"50 e ao "sacrifício da razão".$^{51}$ No entanto, a teologia negativa apresenta uma feição metafísica, em semelhança com a teologia positiva. A teologia negativa implica na assertividade contraditória da existência de um "mistério", com todas as qualificações universais e necessárias do ente que se sabe "existir"; logo, com o ser de Deus tendo as características do ente que existe, sua concepção trágica acompanha as posições teológico-metafísicas especulativas. Dessa maneira, na visão vattimiana, a posição trágica se tornou o último dos equívocos metafísicos da filosofia da religião por usar o conceito metafísico de "existência" para afirmar a realidade de "Deus". Neste sentido, ambas as teologias, positivas e negativas, por sua impostação metafísica, não contribuem para uma culturalização quenótica do cristianismo a serviço da emancipação humana.

Por conseguinte, diante dos dois modelos de cristianismo, a escolha entre o trágico e a secularização quenótica se escora, em síntese, em dois critérios antitéticos de análise: 1) na ideia de uma "natural propensão do homem para se pensar dependente de um ser supremo", ${ }^{52}$ projetando na figura de "Deus" seus desejos, consoante a crítica de Feuerbach e Marx; 2) no interesse em transformar o sagrado em "esperanças de redenção política" 53 - transformação que resgata positivamente, para Rorty, uma afirmação que, para Nietzsche, era depreciativa: "A democracia é o cristianismo tornado natural" ${ }^{54}$ Por conta dessa dimensão política transformadora, o melhor paradigma de cristianismo, para Vattimo, é o do abaixamento de Deus pela Encarnação, que incide numa concepção enfraquecedora do divino por fazer da ação histórica um lugar especial de sua revelação. Consequentemente, a melhor experiência cristã é a democracia laica em benefício dos direitos humanos.

Esse modo esvaziado e plural de tratar a fé gera a ambiguidade da expressão "acreditar em acreditar". ${ }^{55}$ Ao enunciar que crê que continua crendo, o pensador turinense subverte a impostação metafísica da aposta pascaliana, no fragmento 233 da obra Pensamentos ${ }^{56}$. Também Vattimo convida seus contemporâneos à fé por uma aposta. Essa aposta - de

\footnotetext{
${ }^{50}$ GIORGIO, G. Il pensiero di Gianni VATTIMO, G. 2006, p. 257.

51 VATTIMO, G. Acreditar em acreditar, 1998, p. 49.

${ }^{52}$ VATTIMO, G. Acreditar em acreditar, 1998, p.2 9.

53 VATTIMO, G. Acreditar em acreditar, 1998, p. 12.

${ }^{54}$ NIETZSCHE, F. apud: RORTY \& VATTIMO, G. 2006, p. 99.

55 VATTIMO, G. Acreditar em acreditar, 1998, p.9 3.

56 PASCAL, B. Pensamentos, 1971.
} 
caráter interpretativo e não-racionalista - se baseia na confiança de que um dia realizar-se-á o que agora só nos caberia o risco de acreditar ${ }^{57} \mathrm{~A}$ crença religiosa participa de um arriscado jogo de interpretações. Para não se enredar numa discussão acerca dos aspectos metafísicos da fé - tais como as "provas" da existência de "Deus" e a dupla natureza de Cristo -, os conteúdos da fé precisam converter-se em "simbólicos". Um olhar "simbólico", em sentido lato, da fascinante mensagem bíblica suscita uma polissemia facilitadora da escuta contemporânea da fé.

A ressignificação dos conteúdos da revelação seria uma consequência da própria fé diante da contínua historicidade da revelação bíblica pela encarnação. O mito de um ser divino que se "esvazia" por amor, historiciza também a maneira de o entender. A especificidade do mito cristão é a encarnação e a encarnação demanda uma historicidade no modo e no conteúdo de se referir a Deus e nomeá-lo. Renomear Deus, então, seria um desafio constante e uma ousadia interpretativa para cada crente e para sua comunidade, sob o risco de incompreensão.

Assim, a radicalidade paradoxal da encarnação esvazia a condição transcendente e misteriosa de Deus. A encarnação evoca a perda de fundamentos estáveis, absolutos e eternos, concebendo Deus e a religião num projeto ético-político e sem estimular afirmações teóricas e objetivantes da realidade divina. Contra tal objetivação, insurge-se a desvalorização nietzschiana como oportunidade de múltipla valoração:

[...] a desvalorização diz respeito aos valores supremos, mas não a todos os valores, porque ele queria que se criassem sempre novos valores ou nascessem sempre novos deuses. Esse é o ponto: nós devemos constituir uma ética do projeto, e não uma ética do reflexo da natureza, da ordem, do necessário, etc. ${ }^{58}$

Vai ao encontro desse tipo de cristianismo, o anúncio nietzschiano da "morte de Deus". A morte do Deus-moral da metafísica não proclama metafisicamente a verdade da inexistência de Deus ${ }^{59}$ mas sua transvaloração. Tal anúncio acompanharia a secularização do ambiente histórico-cultural de contemporâneos alemães quanto ao luteranismo da época. Esse anúncio evoca a atuação historicizante da Kénosis de maneira semelhante ao dos mezzo credenti..$^{60}$

Ainda que seja um fenômeno sociológico complexo e mais comum em setores urbanos - o que não compete a este artigo - , a retórica vattimiana rejeita esquemas metafísicos repressivos pela enaltação dos "meio crentes", que se orientariam pelo princípio da caritas/pietas ${ }^{61}$. Independentemente da

\footnotetext{
${ }^{57}$ VATTIMO, G. Acreditar em acreditar, 1998, p. 93.

${ }^{58}$ VATTIMO, G. Entrevista: "pensamento fraco", 2001, p. 09.

${ }^{59}$ VATTIMO, G. Para além da interpretação, 1999, p. 19.

${ }^{60}$ VATTIMO, G. Acreditar em acreditar, 1998, p. 56.

${ }^{61}$ PECORARO, R. Niilismo e (pós)modernidade, 2005, p. 116.
} 
questão sociológica, sobretudo na Itália, tal retórica favorece visões alternativas e diluidoras de compreensões reificadas do religioso. Em tese, o desafio de se acolher "meio crentes" manifesta o influxo da ação quenótica-secularizante no cristianismo oposta a seu modelo muscular. A herança cristã, culturalizando-se democraticamente, enfraquece-se salutarmente numa ética e política protagonizada pela Kénosis. A caritas/pietas é, portanto, uma atitude ética, política e cultural em prol de um esforço hermenêutico dialogante como meio de historicização das afirmações acerca de Deus.

A ação quenótica, aquém e além da tradição cristã, mostra a ausência de limite do amor divino. Para corroborar essa posição, Vattimo retoma a conhecida frase agostiniana, ama e faze o que quiseres (Dilige, et quod vis fac). ${ }^{62} \mathrm{O}$ amor é o sentido, limite e filtro da ação quenótica ${ }^{63} \mathrm{e}$, por isso, as práticas e os conteúdos dos artigos de fé deveriam ressignificar-se histórica e existencialmente a partir de um processo de diálogo a ser promovido pelo amor-caritas/pietas como princípio hermenêutico. A ação quenótico-emancipatória acolhe não só quem nos é próximo, mas especialmente a estranheza do outro, particularmente em sua diversa experiência do religioso. A acolhida amorosa do outro na sua diferença qualifica positivamente a desmitologização quenótica atuando na experiência religiosa - atente-se para o valor de um modelo recente de cristianismo efetivamente quenótico que chega, em sintonia com a citação acima, ao paradoxo de elaborar uma "teologia do pluralismo religioso".

A revelação bíblica se sintetiza num acolhimento em que nada mais é definitivo e tudo é "secularizável" ou relativizável, esvaziável e ironizável, menos o amor-caritas/pietas, cuja abertura sem fim ao diálogo é extensão do mandamento supremo de amar. Mandamento que sintetiza o texto bíblico e, numa circularidade hermenêtica, que sustenta e inspira a desmitologização das hierofanias violentas por uma ação quenótica-secularizante. ${ }^{64}$ Por isso, a exemplo dos meio crentes, Vattimo considera o anticlericalismo de Voltaire, no contexto iluminista, como um "efeito positivo da cristianização autêntica da humanidade e não um blasfemo inimigo de Cristo" ${ }^{65}$

Para entender essa desmitologização pós-metafísica, Vattimo conjuga a ação quenótica com os horizontes de pensamento de Nietzsche e Heidegger para propor o esvaziamento do ser metafísico. A metafísica remete a algo estável. Essa estabilidade se caracteriza pela negação da historicidade. Apesar dessa sua desvalorização da historicidade de suas afirmações, a metafísica participou e foi útil historicamente na eventualidade da errância do ser enquanto acontecimento. Vemos, então, a densidade de um pensamento de

\footnotetext{
${ }^{62}$ AGOSTINHO; apud: VATTIMO, G. Acreditar em acreditar, 1998, p. 59.

63 VATTIMO, G. Acreditar em acreditar, 1998, p. 71.

${ }^{64}$ VATTIMO, G. Acreditar em acreditar, 1998, p. 62.

65 VATTIMO, G. Acreditar em acreditar, 1998, p. 33.
} 
matriz heideggeriana em que uma posição fortemente estruturante do real seja paradoxalmente uma oportunidade para se reconhecer manifestações históricas da ação quenótica.

Por conseguinte, mesmo na época do "fim da metafísica", o movimento de diminuir, subtrair e enfraquecer o objetivismo, em particular pela Filosofia e pela Teologia, nunca finaliza, pois não se chega a uma negação completa e cabal da ontoteologia. Isso seria como chegar objetivamente à verdade real dos fatos, porém, diria Nietzsche, "não há fatos, somente interpretação". ${ }^{66}$ Frase retomada por nosso autor com um pequeno e importante acréscimo pessoal, com o fito de excluir a feição metafísica dessa afirmação nietzschiana: "e também isto, claro, é uma interpretação, não é?" 67

O enfraquecimento niilista do "mundo verdadeiro" da ontoteologia converte o mundo, pela ação quenótica, em um jogo de interpretações, o que permite um reencontro niilista do cristianismo numa nova visão de mundo ou, mais precisamente, num novo mundo. A reconstrução quenótica perpassa a história cultural do Ocidente em especial pelo anúncio nietzschiano da morte do Deus-moral da ontoteologia, ressignificando culturalmente o mito cristão e dos conteúdos da revelação em novos termos, "conformes ao século". ${ }^{68}$ Vemos, então, que Vattimo "torce" hermeneuticamente o sentido usual do enfraquecimento niilista ao articulá-lo com a ação quenótica.

O niilismo hermenêutico - por seu caráter processual - efetiva-se, por conseguinte, como núcleo da história da salvação marcada pela Kénosis. A secularização quenótica participa da história da salvação quando historiciza a leitura ontoteológica da revelação e dos conteúdos da fé69; no entanto: "Em seu retorno à religião, a consciência comum tende a se comportar de modo reativo. Em outras palavras, tende a se desdobrar como busca nostálgica de um fundamento último e inabalável." ${ }^{\prime 70}$ Essa nostalgia, porém, não é a vocação quenótica do cristianismo.

O Ocidente foi gestado e plasmado pela mensagem cristã, o que não implica numa "cultura cristã" específica, como a Cristandade. Caso assim fosse, numa hipótese extrema, a herança cristã não permitiria o reconhecimento democrático de novas e múltiplas expressões religiosas, isso seria como se um europeu-muçulmano não pudesse ser considerado um "verdadeiro" europeu. Inversamente, o ser que vem como apelo e proveniência (Geschick), através da hermenêutica, atende ao chamado epocal. ${ }^{71} \mathrm{Na}$ época do fim da metafísica essa proveniência se associa a uma tarefa indispensável de

\footnotetext{
${ }^{66}$ NIETZSCHE, F. apud: VATTIMO, G. 1999, p. 19.

${ }^{67}$ VATTIMO, G. Para além da interpretação, 1999, p. 19.

${ }^{68}$ VATTIMO, G. Acreditar em acreditar, 1998, p. 72.

${ }^{69}$ VATTIMO, G. Para além da interpretação, 1999, p. 9.

${ }^{70}$ DERRIDA, J. \& VATTIMO, G. G. (orgs.). A religião, 2000, p. 96.

${ }^{71}$ VATTIMO \& ZABALA, Hermeneutic Communism, 2011a, p. 110.
} 
"distorção" (Verwindung) da consciência histórica igualmente no tocante ao "fim da metafísica" - como sinalizara Nietzsche a respeito do "excesso de consciência historiográfica"72 . A ontologia de Vattimo ausculta o apelo enfraquecido do legado religioso do Ocidente - a "terra do crepúsculo" - como lugar da declinação do ser ${ }^{73}$, como se a metafísica fosse uma doença da qual o Ocidente se convalesce ${ }^{74}$ e cuja cura exigisse uma "distorção transformadora" (Verwindung) da metafísica pelo reconhecimento do "ser como evento". O ser acontece como evento de distorção da estabilidade do ser como simples-presença ${ }^{75} \mathrm{~A}$ ontologia, determinada pela Kénosis, enfraquece as estruturas metafísicas do ser quando preconiza novas interpretações ético-políticas do "real" pela escuta do apelo à morte do Deus-moral.

A partir da diferença ontológica entre ser e ente, a Verwindung pensa a verdade do ser como o apelo da mensagem evangélica transmitida pela tradição cristã. Tradição a ser rememorada (Andenken) como uma escuta dessa tradição. Uma escuta que, no cristianismo, parte do seio de sua tradição como caritas/pietas, enfraquecendo os elementos musculares dessa tradição cristã. Desse modo, a distorção enfraquecida da ontoteologia ${ }^{76}$ como apelo quenótico ao cristianismo, assume a proveniência "monumental" do cristianismo, quando se assume a historicidade do cristianismo como patrimônio cultural. O cristianismo como patrimônio cultural esvazia seu tipo mais dogmático e o enfraquece hermeneuticamente a serviço da democracia $^{77}$

O caráter redundantemente histórico da monumentalidade não significa, para Vattimo, a permanência de estruturas de poder a serem perpetuadas - como se fossem estátuas de colonizadores escravocratas -; ao contrário, a monumentalidade do cristianismo persiste por seu peso simbólico enquanto fundo musical de nossa vida comum; como apelo quenótico ao que há de melhor no seio da sociedade democrática. A monumentalidade do cristianismo o enfraquece e distorce pela ação da Kénosis para que permaneça sua seiva vital através da ruína do que já passou e ficou para trás ou deveria ficar para trás, como a Cristandade. Não cabe, portanto, um laicismo belicoso de combate ao cristianismo e a seus símbolos, mas esvaziar o peso metafísico deles ao reconhecê-los como patrimônio cultural e como apelo à maior justiça social aos mais fracos. $\mathrm{O}$ esvaziamento quenótico do cristianismo permite uma sua paradoxal atualização político-cultural diante de sempre novas circunstâncias.

\footnotetext{
72 VATTIMO, G. As Aventuras da Diferença, 1988, p. 21.

${ }^{73}$ VATTIMO, G. Depois da cristandade, 2004, p. 38.

74 DERRIDA, J. \& VATTIMO, G. G. (orgs.). A religião, 2000, p. 91.

75 VATTIMO, G. Dialettica, differenza e pensiero debole, 1983b, p. 22.

${ }^{76}$ VATTIMO, G. O fim da modernidade. Martins Fontes, São Paulo, 2002, p. 28.

77 VATTIMO, G. O fim da modernidade. Martins Fontes, São Paulo, 2002, p. 82.
} 


\section{Considerações Finais}

O "cristianismo", no singular, se constituiu como a tradição narrativa vitoriosa sobre outras versões. Embora essa versão vencedora também seja uma construção histórica e historicizável. Assim, nosso autor propôs exatamente reconhecer isso pela historicização dessa narrativa em vista de pretensões emancipatórias na época do fim da metafísica.

Seu objetivo não nega a herança cristã mas resgata seu núcleo central: a ação da Kénosis divina como eixo desse processo histórico de salvação, como da história ocidental. A encarnação já pressupõe o valor dessa hermenêutica no âmago de seu mito fundante. A Kénosis divina perpassa a mensagem de acolhida dos fracos como um princípio de ação ético-política. Logo, a secularização de leituras violentas e fundamentalistas se entrelaçam com as posições de Nietzsche e Heidegger, respectivamente, de transvaloração e de distorção da metafísica, como também pela Kénosis que tensamente se inscreve no cristianismo.

Uma adicional e inaudita análise de nosso autor é a equiparação que realiza entre as teologias positiva e negativa no tocante aos pressupostos metafísicos de ambas quanto à existência do ser divino. Essa posição causa assombro pelo peso que a fenomenologia da religião adquiriu na contemporaneidade, exatamente como tentativa de pensar o religioso sem as amarras normativas da positividade teológica. Caberia, no entanto, radicalizar uma culturalização do sagrado que esvazie sua substancialidade pressuposta.

Há muitas vertentes de futuras pesquisas a partir desse horizonte aberto pelo pensiero debole. O enfraquecimento ontológico do cristianismo por sua cultural historicização, converte em narração sua herança; em sintonia com o fazer literário. Encontra-se aqui a relevância hermenêutica de uma "teologia narrativa", riqueza que se estende à semântica dos textos místicos, com sua incidência no estudo da subjetividade em contexto pós-metafísico. Tais possibilidades compõem o escopo de uma ampla transformação do religioso, e portanto do cristianismo, para nossos contemporâneos que vivem num mundo em que a verdade se transfigurou em fábula, nos dizeres de Nietzsche. ${ }^{78}$

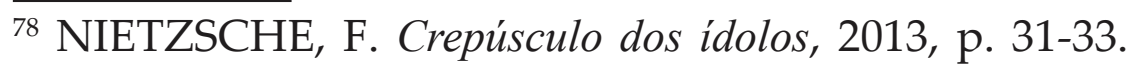




\section{Referências:}

A BíBLIA DE JERUSALÉM. São Paulo: Paulus, 2006.

DERRIDA, J. \& VATTIMO, G. G. (orgs.). A religião: o seminário de Capri. São Paulo: Estação Liberdade, 2000.

ELIADE, M. O sagrado e o profano: a essência das religiões. São Paulo: Martins Fontes, 2001.

GADAMER, H.-G. A Razão na época da ciência. Rio de Janeiro: Tempo Brasileiro, 1983a.

GIORGIO, G. Il pensiero di Gianni Vattimo: l'emancipazione della metafisica tra dialettica ed ermeneutica. Milano: Franco Angeli, 2006.

GIRARD, R. A Violência e o Sagrado. São Paulo: Paz e Terra/UNESP, 1990.

HEIDEGGER, M. Nietzsche. Rio de Janeiro: Forense Universitária, 2007, v. 2.

KIERKEGAARD, S. A. Temor e tremor. São Paulo: Abril Cultural, 1979.

NIETZSCHE, F. Crepúsculo dos ídolos, ou como se filosofa com o martelo. São Paulo: Companhia das Letras, 2013.

PASCAL, B. Pensamentos. São Paulo: Abril, 1971.

PECORARO, R. Niilismo e (pós)modernidade: introdução ao "pensamento fraco" de Gianni Vattimo. Rio de Janeiro/São Paulo: Ed. PUC-Rio/Loyola, 2005.

RORTY, R. \& VATTIMO, G. G. O Futuro da Religião - solidariedade, caridade e ironia. Rio de Janeiro: Relume Dumará, 2006.

VATTIMO, G. Dialettica, differenza e pensiero debole. In: \& ROVATTI, A. P. (orgs.) Il Pensiero Debole. Milano: Feltrinelli Editore, 1983b.

VATTIMO, G. As Aventuras da Diferença: o que significa pensar depois de Heidegger e Nietzsche. Lisboa: Edições 70, 1988.

VATTIMO, G. Etica dell'Interpretazione. Torino: Rosenberg \& Sellier, 1989.

VATTIMO, G. Acreditar em acreditar. Lisboa: Relógio D’Água, 1998.

VATTIMO, G. Para além da interpretação: o significado da hermenêutica para a filosofia. Rio de Janeiro: Tempo Brasileiro, 1999.

VATTIMO, G. Entrevista: O filósofo italiano Gianni Vattimo fala de seu "pensamento fraco". In: CULT, n. 44, março/2001, p 4-9.

VATTIMO, G. O fim da modernidade. Martins Fontes, São Paulo, 2002.

VATTIMO, G. Nichilismo ed emancipazione. Etica, política, diritto. Milano: Garzanti, 2003.

VATTIMO, G. Depois da cristandade: por um cristianismo não religioso. Rio de Janeiro: Record, 2004.

VATTIMO, G. Entrevista: O meu problema de cristão é que a Igreja me escandaliza. In: PÚBLICO, 09mar2008a. Disponível em: 
https://www.publico.pt/2008/03/09/jornal/o-meu-problema-de-cristao-e-que-a-igreja-me-escandaliza-252455 Acesso em: 10mar2020.

VATTIMO, G. Entrevista: O capitalismo é, em grande parte, responsável pela infelicidade. In: CULT, n. 126, julho/2008b, p. 12-15.

VATTIMO, G. \& ZABALA, S. Hermeneutic Communism: From Heidegger to Marx. Columbia University Press, 2011.

VATTIMO, G. Essere e dintorni. Milano: La Nave di Teseo, 2018.

WEBER, M. A ética protestante e o "espírito" do capitalismo. São Paulo: Companhia das Letras, 2004.

Endereço ao Autor:

Graciano Neves, 314

Centro

29015-330 Vitória - ES

marcelobarreira@ymail.com 